\title{
Dinamika Penyebaran Campak Dengan Pangaruh Migrasi
}

\section{Dynamics On The Spread Of Measles With Migration Effect}

\author{
Lazarus Kalvein Beay ${ }^{1,2,3)}$ *
}

${ }^{1)}$ SMA Negeri 1 Teluk Elpaputih, Dinas Pendidikan dan Kebudayaan Provinsi Maluku

2) SMA Negeri 3 Teluk Elpaputih, Dinas Pendidikan dan Kebudayaan Provinsi Maluku

3) Jurusan Pendidikan MIPA/ Program Studi Pendidikan Matematika, STKIP Gotong Royong Masohi

Received $17^{\text {th }}$ June $2018 /$ Accepted $20^{\text {th }}$ Septemer 2018

\begin{abstract}
ABSTRAK
Migrasi merupakan salah satu parameter penting dalam penyebaran penyakit, tak terkecuali campak. Penelitian ini bertujuan mengkaji pengaruh parameter imigrasi dan emigrasi pada penyebaran campak. Metode yang digunakan yaitu studi literatur untuk menentukan variabel dan parameter yang digunakan untuk mendesain model. Data yang digunakan untuk simulasi adalah data sekunder yang diperoleh dari penelitian-penelitian sebelumnya. Dengan menentukan bilangan reproduksi dasar, dapat dilakukan analisa terhadap parameter migrasi pada penyebaran campak. Hasil simulasi menunjukkan bahwa bilangan reproduksi dasar dari model monoton naik ketika imigrasi meningkat. Selain itu, bilangan reproduksi dasar dari model monoton turun ketika emigrasi meningkat. Hasil tersebut menunjukkan bahwa migrasi yang terjadi dalam populasi memiliki pengaruh pada penyebaran campak.
\end{abstract}

Kata kunci: campak, model, migrasi, bilangan reproduksi dasar.

\begin{abstract}
Migration is one of the important parameters in the spread of disease, including measles. This study aims to examine the effect of immigration and emigration parameters on the spread of measles. The method used is literature study to determine the variables and parameters used when designing the model. The data used for simulation is secondary data obtained from previous studies. By determining the basic reproduction number, an analysis of migration parameters can be performed on the spread of measles. Simulation results show that the basic reproduction number of the model is monotonically increasing as immigration increasing. Next, the basic reproduction number of the model is monotonically decreasing as the emigration increasing. The results show that the migration process affects the spread of measles.
\end{abstract}

Keywords: measles, model, migration, basic reproduction number.

*Korespondensi:

email: kalvinbeay@gmail.com 


\section{PENDAHULUAN}

Campak merupakan penyakit yang sangat menular. Penyakit ini disebabkan oleh virus campak golongan Paramyxovirus (Soegijanto dan Salimo, 2011; WHO, 2015). Penyakit ini biasanya terjadi karena kontak langsung dengan penderita. Pada umumnya, gejala penyakit ini akan muncul 10-12 hari setelah tertular virus (Pang dkk, 2015; WHO, 2015). Gejala awal dari penyakit ini adalah demam, bercak kemerahan, batuk, pilek, dan konjunctivitis (mata merah), selanjutnya timbul ruam (bintik kemerahan) pada muka dan leher, kemudian menyebar ke tubuh dan tangan serta kaki. Masa penularan biasanya terjadi 4 hari sebelum muncul gejala dan 4 hari setelah muncul gejala pada penderita. Tidak ada pengobatan khusus untuk penyakit tersebut. Salah satu strategi untuk mencegah penyebaran penyakit adalah dengan melakukan vaksinasi campak secara rutin kepada anak (WHO, 2015). Namun sampai saat ini campak masih menjadi masalah kesehatan di dunia (Pang dkk, 2015; WHO, 2015). Menurut data World Health Organization (WHO, 2015) bahwa pada tahun 2013 terjadi 143.700 kematian yang disebabkan oleh campak di seluruh dunia (berkisar 16 kematian setiap hari). Penyakit ini sangat berbahaya, karena dapat menyebabkan komplikasi seperti kerusakan otak, cacat seumur hidup, kelumpuhan bahkan kematian.

Model matematika pada penyebaran penyakit merupakan suatu hal yang menarik untuk dikaji. Hal ini disebabkan model matematika merupakan pilihan yang tepat untuk memahami permasalahan yang kompleks pada penyebaran penyakit. Berbagai model telah dihasilkan pada berbagai penularan infeksi penyakit yang berbeda. Melalui berbagai model yang dihasilkan tersebut dapat diupayakan strategi untuk mengontrol penularan berbagai penyakit tersebut (Fabricius dkk, 2013; Maltz dan Fabricius, 2016; Beay dkk, 2017; Huang dkk, 2017).

Migrasi penduduk merupakan perpindahan penduduk dari tempat yang satu ke tempat yang lain. Adapun faktor-faktor yang mempengaruhi migrasi penduduk antara lain persediaan sumber daya alam, lingkungan sosial budaya, politik, ekonomi, tujuan masa depan, termasuk juga wabah penyakit (Wang dan Wang, 2012; Jody dan Joyceen, 2015). Menurut Sari dan Augeraud-Véron (2015), bahwa dengan mempertimbangkan faktor migrasi yang terjadi dalam populasi dapat mengurangi jumlah infeksi penyakit. Hal ini disebabkan oleh pola migrasi yang terjadi dalam suatu populasi dapat menjadi salah satu faktor penyebaran penyakit (Wang dan Wang, 2012; Beay dkk, 2017). Menurut Tam (2006), dengan berfokus pada masalah kesehatan akan dapat mengatasi patologi sosial. Dengan demikian analisa perilaku dinamika penyebaran campak dengan pengaruh migrasi menjadi fokus penelitian yang sangat penting untuk dikaji, karena akan memberikan informasi yang membantu dalam penanganan penyakit secara optimal.

\section{METODE PENELITIAN}

Penelitian ini pada dasarnya dilakukan dengan tahapan-tahapan sebagai berikut:

a. Melakukan studi literatur mengenai proses penyebaran penyakit yang akan dimodelkan khususnya mengenai penyebaran campak dengan pengaruh migrasi. 
b. Pencarian data sekunder yaitu data yang diperoleh dari penelitian-penelitian sebelumnya untuk keperluan simulasi.

c. Pengumpulan semua variabel dan parameter model yang diperoleh dari identifikasi masalah.

d. Mendesain model matematika dari masing-masing proses yang terjadi pada populasi yang rentan, terinfeksi, karantina hingga penyembuhan.

e. Melakukan analisis secara kualitatif terhadap model yang telah dibangun.

f. Mengiterpretasi hasil yang diperoleh untuk mengetahui pengaruh migrasi dalam penyebaran penyakit.

g. Melakukan simulasi solusi model.

\section{HASIL DAN PEMBAHASAN}

\section{Model Penyebaran Campak}

Dalam pembentukan model penyebaran campak dengan pengaruh migrasi, terdapat beberapa asumsi sebagai berikut:

a. Jumlah individu pada kelas rentan (susceptible) akan bertambah karena laju kelahiran $\Lambda$ dan laju imigrasi $\delta_{1}$.

b. Ketika terjadi infeksi maka jumlah individu pada kelas terinfeksi (infected) akan bertambah dengan laju $\alpha$.

c. Untuk mengurangi efek kontak dengan penderita maka dilakukan karatina laju $\beta$.

d. Jumlah individu pada kelas sembuh (recovered) akan bertambah karena penyembuhan yang terjadi pada kelas infeksi (infected) dengan laju $\eta$ dan yang terjadi pada kelas karantina dengan laju $\gamma$.

e. Jumlah individu pada kelas infeksi (infected) dan karantina (quarantined) akan berkurang disebabkan kematian karena penyakit dengan laju $\varphi$.

f. Jumlah individu kelas rentan (susceptible), infeksi (infected), karantina dan sembuh (recovered) akan berkurang karena kematian yang terjadi secara alami dengan laju $\mu$.

g. Jumlah individu pada kelas rentan (susceptible), infeksi (infected), dan sembuh (recovered) akan berkurang karena proses emigrasi dengan laju $\delta_{2}$.

Berdasarkan pada asumsi-asumsi di atas, maka skema proses penyebaran penyakit dapat disajikan pada Gambar 1.

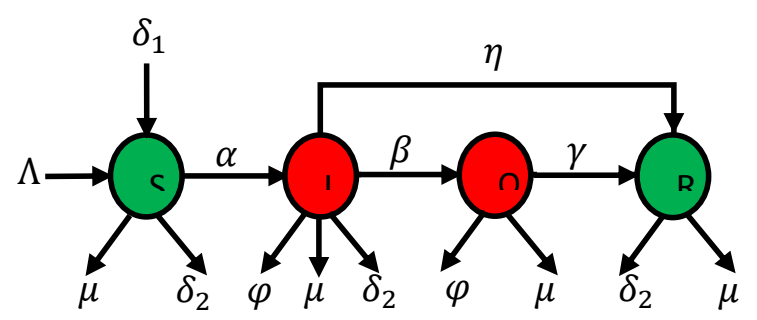


Dari diagram transfer pada Gambar 1, maka diperoleh sistem persamaan differensial sebagai berikut:

$\frac{d S}{d t}=\left(\Lambda+\delta_{1}\right)-\alpha S I-\left(\mu+\delta_{2}\right) S$

$\frac{d I}{d t}=\alpha S I-\eta I-\beta I-\left(\varphi+\mu+\delta_{2}\right) I$

$\frac{d Q}{d t}=\beta I-\gamma Q-(\varphi+\mu) Q$

$\frac{d R}{d t}=\eta I+\gamma Q-\left(\mu+\delta_{2}\right) R$

Dengan kondisi awal model $S(0)=S_{0}, I(0)=I_{0}, Q(0)=Q_{0}, R(0)=R_{0}$.

\section{Solusi Steady State}

Dengan menjadikan model (1) sama dengan nol, maka diperoleh solusi steady state yang pertama:

$\varepsilon_{0}=\left(S_{0}, I_{0}, Q_{0}, R_{0}\right)=\left(\frac{\Lambda+\delta_{1}}{\mu+\delta_{2}}, 0,0,0\right)$.

Solusi ini disebut titik kesetimbangan bebas penyakit karena tidak terdapat infeksi di dalam populasi. Selanjutnya solusi steady state yang kedua adalah

$\varepsilon_{1}=\left(S_{1}, I_{1}, Q_{1}, R_{1}\right)==\left(\frac{\theta}{\alpha}, \frac{\rho}{\theta}, Q_{1}, R_{1}\right)$.

dengan

$Q_{1}=\frac{(\beta-\gamma) \rho}{(\mu+\varphi) \theta}$

$R_{1}=\frac{\rho\left(\beta \gamma+\eta \mu+\eta \varphi-\gamma^{2}\right)}{\theta(\mu+\varphi)\left(\mu+\delta_{2}\right)}$

$\theta=\left(\beta+\eta+\mu+\varphi+\delta_{2}\right)$

$\rho=\Lambda+\delta_{1}-\frac{\left(\mu+\delta_{2}\right) \theta}{\alpha}$

Solusi ini disebut titik kesetimbangan endemik karena terdapat infeksi di dalam populasi.

\section{Bilangan Reproduksi Dasar}

Bilangan reproduksi dasar merupakan sesuatu yang penting dalam model epidemik. Bilangan reproduksi dasar dari model (1) ditentukan dengan menggunakan matriks next generation dari model (1). Misalkan $\mathcal{F}_{i}(\boldsymbol{x})$ adalah laju penambahan infeksi baru pada kompartemen $i$ dan $\mathcal{V}_{i}(\boldsymbol{x})$ adalah laju perpindahan individu pada kompartemen $i$ dengan $\boldsymbol{x}=(I, Q)$, maka $\mathcal{F}_{i}(\boldsymbol{x})$ dan $\mathcal{V}_{i}(\boldsymbol{x})$ dari sistem (1) adalah sebagai berikut:

$\mathcal{F}(\boldsymbol{x})=\left(\begin{array}{c}\alpha S I \\ 0\end{array}\right)$ 


$$
\boldsymbol{v}(\boldsymbol{x})=\left(\begin{array}{c}
\eta I+\beta I+\left(\varphi+\mu+\delta_{2}\right) I \\
-\beta I+(\gamma+\varphi+\mu) Q
\end{array}\right)
$$

Maka diperoleh matriks

$$
\begin{aligned}
F & =\left(\frac{\partial \mathcal{F}_{i}}{\partial x_{j}}\left(\Sigma_{0}\right)\right)=\left(\begin{array}{cc}
\alpha\left(\frac{\Lambda+\delta_{1}}{\mu+\delta_{2}}\right) & 0 \\
0 & 0
\end{array}\right) \cdots \cdots \\
V & =\left(\begin{array}{cc}
\frac{\partial \mathcal{V}_{i}}{\partial x_{j}}\left(\Sigma_{0}\right)
\end{array}\right) \\
& =\left(\begin{array}{cc}
\eta+\beta+\varphi+\mu+\delta_{2} & 0 \\
-\beta & \gamma+\varphi+\mu
\end{array}\right) .
\end{aligned}
$$

Diperoleh invers matrik $V$ adalah

$V^{-1}=\left(\begin{array}{cc}\frac{1}{\eta+\beta+\varphi+\mu+\delta_{2}} & 0 \\ \frac{-\beta}{\left(\eta+\beta+\varphi+\mu+\delta_{2}\right)(\gamma+\varphi+\mu)} & \frac{1}{(\gamma+\varphi+\mu)}\end{array}\right)$

Sehingga diperoleh matriks $F V^{-1}$ sebagai berikut:

$F V^{-1}=\left(\begin{array}{cc}\frac{\alpha\left(\Lambda+\delta_{1}\right)}{\left(\eta+\beta+\varphi+\mu+\delta_{2}\right)\left(\mu+\delta_{2}\right)} & 0 \\ 0 & 0\end{array}\right)$

Dengan menyelesaikan persamaan $\operatorname{det}\left(F V^{-1}-\lambda I\right)=0$, maka diperoleh persamaan karakteristik sebagai berikut:

$\lambda^{2}-\left(\frac{\alpha\left(\Lambda+\delta_{1}\right)}{\left(\eta+\beta+\varphi+\mu+\delta_{2}\right)\left(\mu+\delta_{2}\right)}\right) \lambda=0$

Akar-akar dari persamaan karakteristik tersebut adalah:

$\lambda_{1}=0$ dan $\lambda_{2}=\frac{\alpha\left(\Lambda+\delta_{1}\right)}{\left(\eta+\beta+\varphi+\mu+\delta_{2}\right)\left(\mu+\delta_{2}\right)}$

Karena $R_{0}$ merupakan spektral radius dari matriks $F V^{-1}$ maka diperoleh:

$R_{0}=\frac{\alpha\left(\Lambda+\delta_{1}\right)}{\left(\eta+\beta+\varphi+\mu+\delta_{2}\right)\left(\mu+\delta_{2}\right)}$

Teorema 1: Titik kesetimbangan endemik $\varepsilon_{1}$ stabil asimtotik secara lokal jika $R_{0}>1$ dan tidak stabil jika $R_{0}<1$.

\section{Simulasi Numerik}

Pada bagian ini ditunjukkan beberapa simulasi numerik dilakukan untuk melihat dinamika bilangan reproduksi dasar serta kondisi populasi manusia ketika $R_{0}>1$ dan $R_{0}<1$. Dalam hal ini, $R_{0}$ merupakan bilangan reproduksi dasar yang didefinisikan pada persamaan (12). Nilai parameter yang digunakan pada model tersebut disajikan pada Tabel 1. 
Tabel 1. Nilai parameter untuk simulasi model.

\begin{tabular}{ccc}
\hline Parameter & Nilai & Referensi \\
\hline$\Lambda$ & 6 & Huang dkk, 2017 \\
$\alpha$ & 0,02 & Huang dkk, 2017 \\
$\beta$ & 0,17 & Huang dkk, 2017 \\
$\gamma$ & 0,06 & Huang dkk, 2017 \\
$\eta$ & 0,04 & Huang dkk, 2017 \\
$\delta_{1}$ & $0-0,3$ & Asumsi \\
$\delta_{2}$ & $0-0,3$ & Asumsi \\
$\mu$ & 0,1 & Huang dkk, 2017 \\
$\varphi$ & 0,001 & Asumsi \\
\hline
\end{tabular}

Kondisi awal rasio jumlah penduduk pada kelas susceptible, infected, quarantined dan recovered masing-masing adalah $S_{0}=30, I_{0}=15, Q_{0}=10$ dan $R_{0}=0$. Jika tidak terjadi migrasi (imigrasi dan emigrasi) maka nilai $\delta_{1}=\delta_{2}=0$. Dinamika populasi manusia ketika tidak terjadi migrasi ditunjukkan pada Gambar 1.

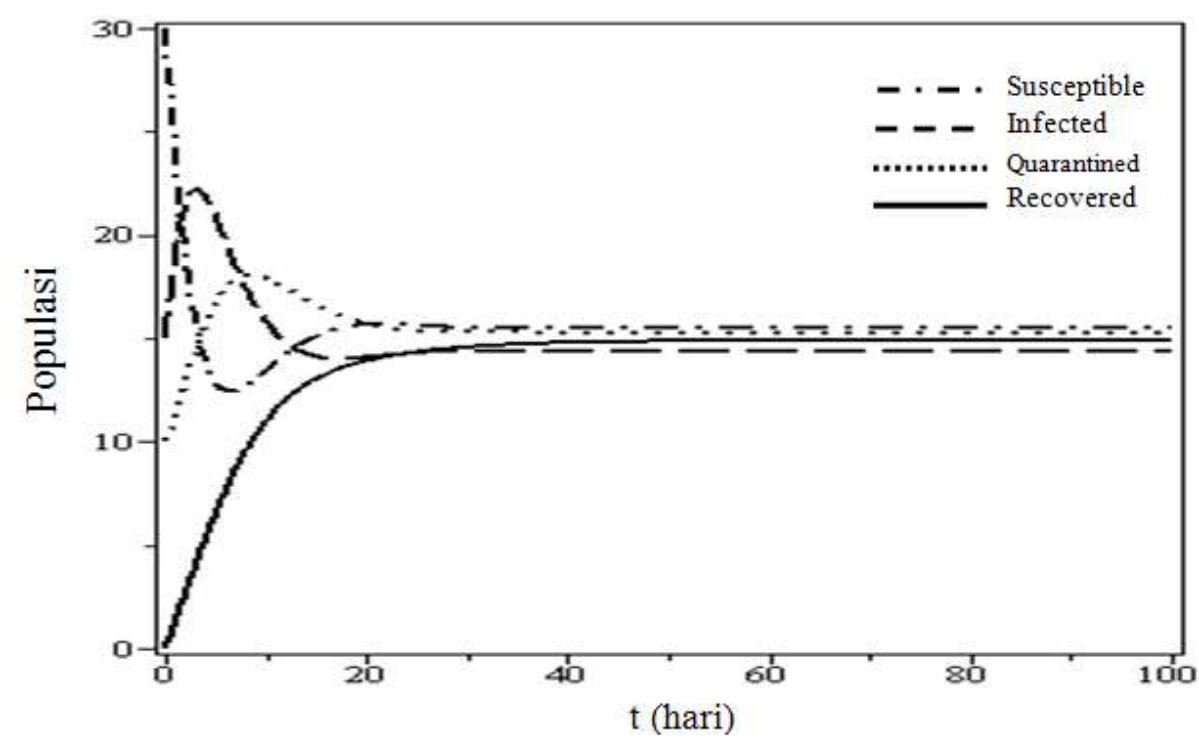

Gambar 1. Kondisi $S, I, Q$ dan $R$ ketika $\delta_{1}=\delta_{2}=0$

Pada kondisi tersebut penyakit berada dalam populasi sampai waktu yang tak tentu. Bilangan reproduksi dasar yang diperoleh $R_{0}=3,86$. Nilai $R_{0}>1$ sehingga titik kesetimbangan endemik $\left(\varepsilon_{1}\right)$ stabil. Nilai variabel $S_{1}, I_{1}, Q_{1}$ dan $R_{1}$ adalah positif. Hal ini berarti terdapat populasi pada setiap kelas tersebut yakni $\varepsilon_{1}=(16,14,15,15)$.

Jika terjadi imigrasi dan tidak terjadi emigrasi $\left(\delta_{1}>\delta_{2}\right.$ dan $\left.\delta_{2}=0\right)$, maka nilai bilangan reproduksi dasar semakin besar. Hal ini mengakibatkan titik kesetimbangan endemik $\left(\varepsilon_{1}\right)$ stabil. Ketika nilai parameter $\delta_{1}=0,1$ maka nilai $R_{0}=3,92$ dan $\varepsilon_{1}=$ $(16,15,15,15)$. Selanjutnya, ketika nilai parameter $\delta_{1}=0,2$ maka nilai $R_{0}=3,98$ dan $\varepsilon_{1}=$ $(16,15,16,15)$. Dan ketika nilai parameter $\delta_{1}=0,3$ maka nilai $R_{0}=4,05$ dan $\varepsilon_{1}=$ $(16,15,16,16)$. Hasil tersebut menunjukkan bahwa semakin besar nilai $\delta_{1}$, maka nilai $R_{0}$ akan semakin besar. Variabel $S_{1}, I_{1}, Q_{1}$ dan $R_{1}$ yang diperoleh bernilai positif . Dinamika 
populasi manusia pada kelas susceptible, infected, quarantined dan recovered ketika terjadi migrasi ditunjukkan pada Gambar 2.
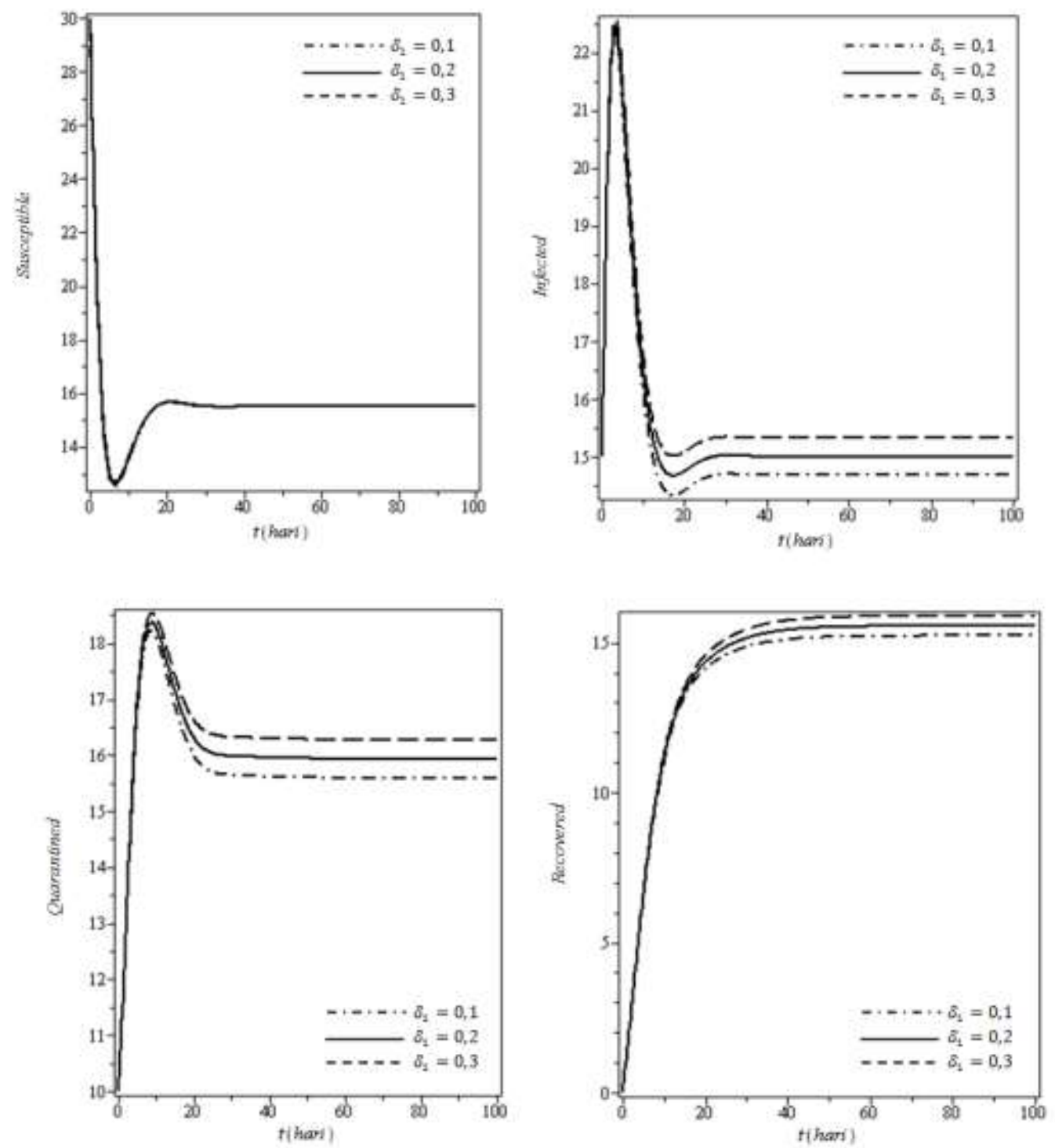

Gambar 2. Kondisi $S, I, Q$ dan $R$ ketika simulasi $\delta_{1}>\delta_{2}$

Pada Gambar 2, menunjukkan bahwa jumlah individu pada kelas susceptible semakin berkurang karena terjadinya infeksi. Jika nilai parameter $\delta_{1}$ semakin meningkat maka jumlah individu pada kelas infected juga mengalami peningkatan. Selanjutnya, jumlah individu pada kelas quarantined akan meningkat karena proses karantina yang dilakukan terhadap individu yang terinfeksi. Setelah mengalami penyembuhan, maka individu akan berpindah ke kelas recovered sehingga jumlah individu pada kelas tersebut mengalami peningkatan. Semakin meningkat nilai parameter $\delta_{1}$, maka semakin meningkat jumlah individu pada kelas infected, quarantined, dan recovered.

Jika terjadi emigrasi dan tidak terjadi imigrasi $\left(\delta_{1}<\delta_{2}\right.$ dan $\left.\delta_{1}=0\right)$, maka nilai bilangan reproduksi dasar semakin kecil. Hal tersebut mengakibatkan titik kesetimbangan endemik $\left(\varepsilon_{1}\right)$ tidak stabil ketika nilai $R_{0}<1$. Ketika nilai parameter $\delta_{2}=0,1$ maka nilai 
$R_{0}=1,46$ dan $\varepsilon_{1}=(21,5,5,2)$. Dari hasil tersebut diperoleh nilai $R_{0}=1,46>1$, sehingga pada kondisi tersebut titik kesetimbangan endemik stabil $(I \neq 0)$. Selanjutnya, ketika nilai parameter $\delta_{2}=0,2$ maka nilai $R_{0}=0,78$ dan $\varepsilon_{1}=(26,-3,-3,-1)$. Hasil tersebut mengakibatkan titik kesetimbangan endemik $\left(\varepsilon_{1}\right)$ tidak stabil. Selain itu, populasi pada kelas infected, quarantined dan recovered bernilai negatif, artinya tidak terdapat populasi pada kelas-kelas tersebut. Dan ketika nilai parameter $\delta_{2}=0,3$, maka nilai $R_{0}=0,49$ dan $\varepsilon_{1}=(31,-10,-11,-3)$. Hasil tersebut menunjukkan bahwa semakin besar nilai $\delta_{2}$, maka nilai $R_{0}$ akan semakin kecil. Hal tersebut mengakibatkan populasi akan terbebas dari penyakit. Dinamika populasi manusia pada kelas susceptible, infected, quarantined dan recovered ketika terjadi emigrasi ditunjukkan pada Gambar 3.
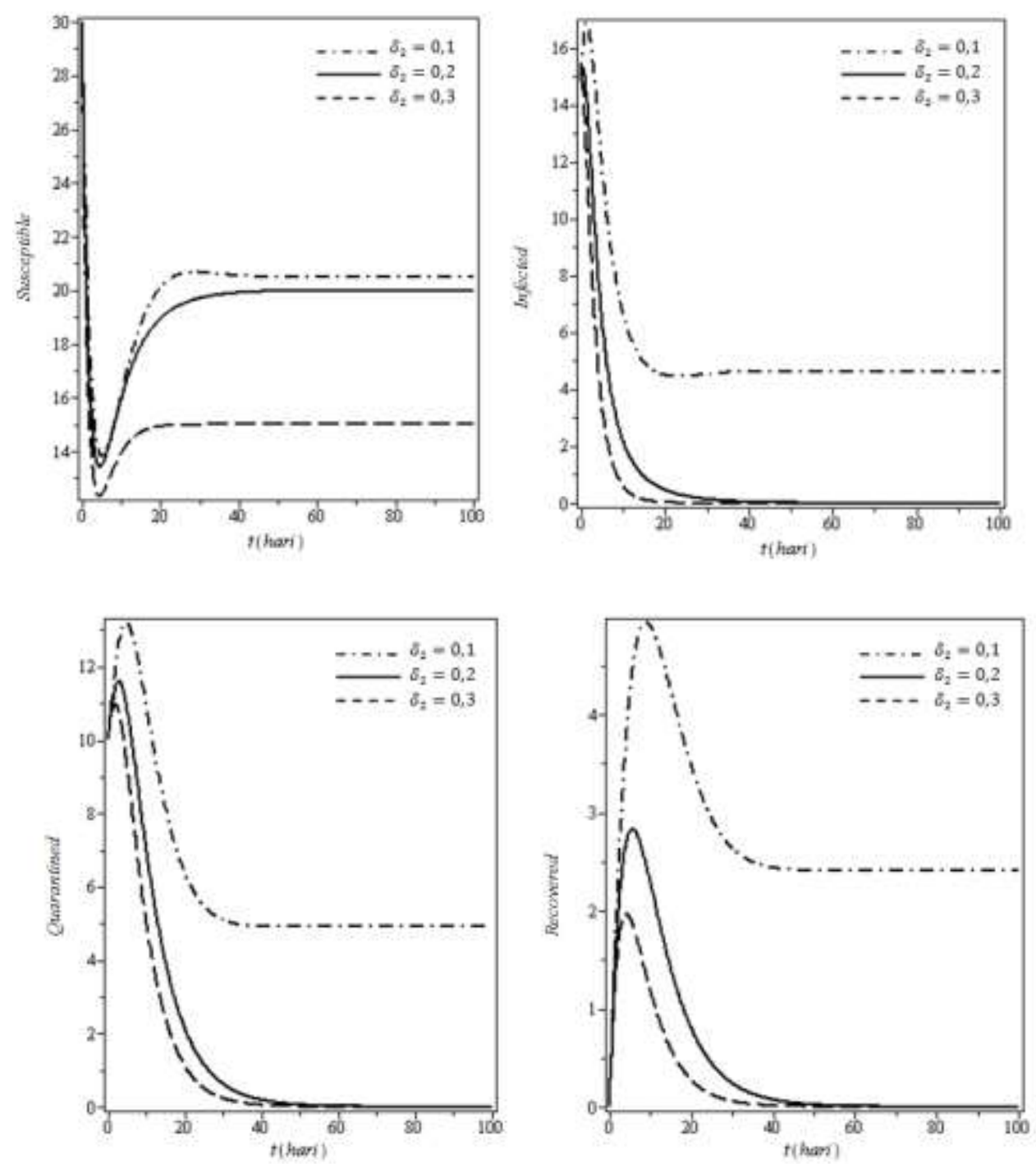

Gambar 3. Kondisi $S, I, Q$ dan $R$ ketika simulasi $\delta_{1}<\delta_{2}$

Pada Gambar 3, menunjukkan bahwa jumlah individu pada kelas susceptible semakin meningkat. Jika nilai parameter $\delta_{2}$ semakin meningkat maka jumlah individu pada kelas infected semakin berkurang. Selanjutnya, jumlah individu pada kelas 
quarantined juga akan berkurang. Setelah mengalami penyembuhan, maka individu akan berpindah ke kelas recovered. Semakin meningkat nilai parameter $\delta_{2}$, maka jumlah individu pada kelas infected, quarantined, dan recovered semakin berkurang. Namun, semakin meningkat nilai parameter $\delta_{2}$, maka jumlah individu pada kelas susceptible semakin meningkat.

Jika proses imigrasi dan emigrasi terjadi dengan laju yang sama $\left(\delta_{1}=\delta_{2}\right)$, maka nilai bilangan reproduksi dasar semakin kecil. Hal ini mengakibatkan titik kesetimbangan endemik $\left(\varepsilon_{1}\right)$ tidak stabil. Ketika nilai parameter $\delta_{1}=\delta_{2}=0,3$ maka nilai $R_{0}=0,52$ dan $\varepsilon_{1}=(31,-10,-10,-3)$. Hasil tersebut menunjukkan nilai $R_{0}<1$. Selain itu, populasi pada kelas infected, quarantined dan recovered bernilai negatif, artinya tidak terdapat populasi pada kelas-kelas tersebut. Dinamika populasi manusia pada kelas susceptible, infected, quarantined dan recovered ketika terjadi imigrasi dan emigrasi ditunjukkan pada Gambar 4.

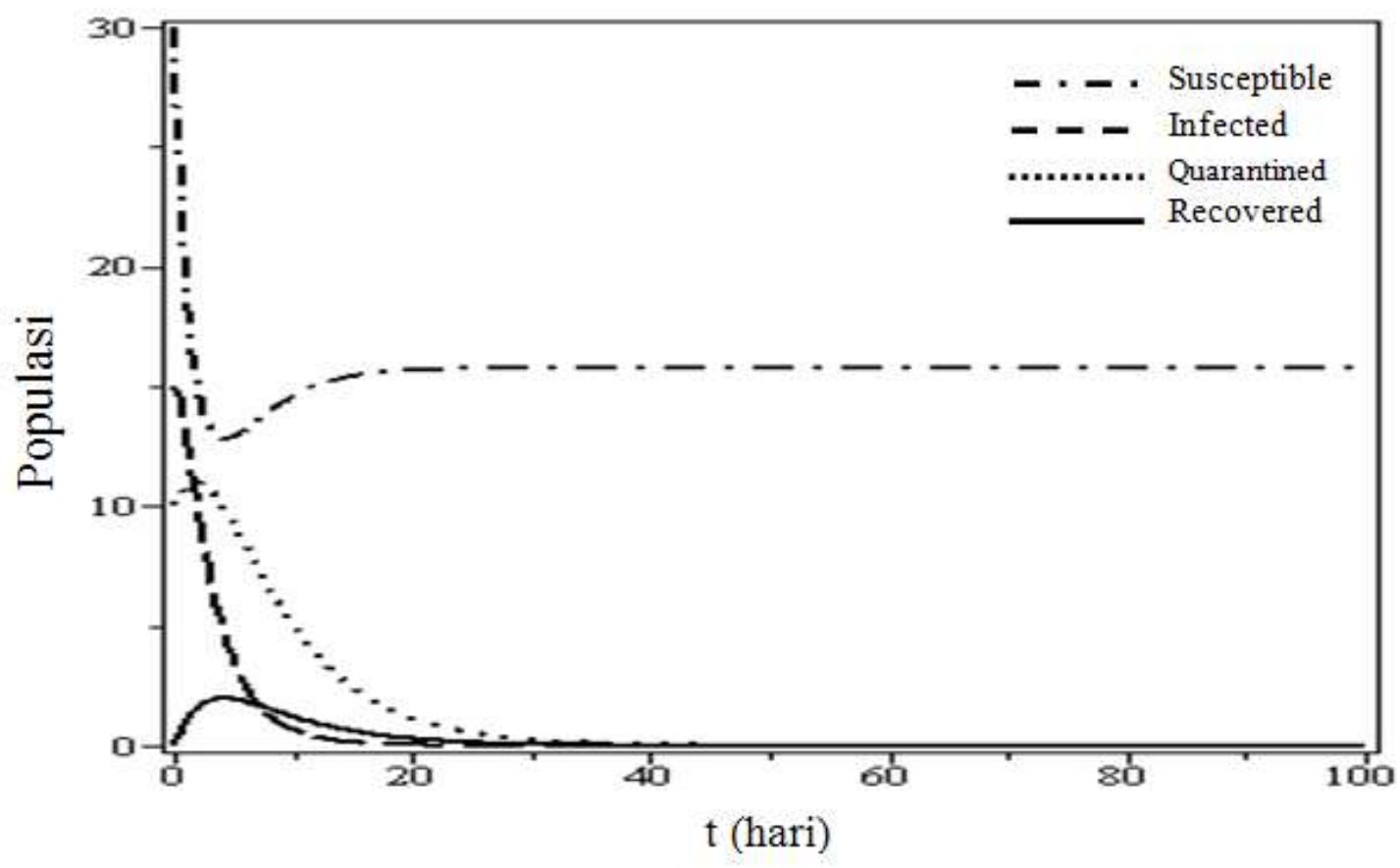

Gambar 4. Kondisi $S, I, Q$ dan $R$ ketika $\delta_{1}=\delta_{2}=0,3$

Pada Gambar 5-(a) ditunjukkan perubahan nilai $R_{0}$ ketika $0 \leq \delta_{1} \leq 1$. Semakin besar nilai parameter $\delta_{1}$, maka semakin besar nilai $R_{0}$. Hal ini berarti semakin besar imigrasi yang terjadi di dalam populasi, maka semakin besar peluang terjadi endemik di dalam populasi. Selanjutnya, pada Gambar 5-(b) ditunjukkan perubahan nilai $R_{0}$ ketika $0 \leq \delta_{2} \leq 1$. Semakin besar nilai parameter $\delta_{2}$, maka semakin kecil nilai $R_{0}$. Artinya semakin besar emigrasi yang terjadi dalam populasi, maka semakin kecil peluang terjadi endemik di dalam populasi. Pada Gambar 5-(c) menunjukkan nilai-nilai dari parameter imigrasi $\left(\delta_{1}\right)$ dan emigrasi $\left(\delta_{2}\right)$ yang dapat mengontrol penyebaran penyakit. 


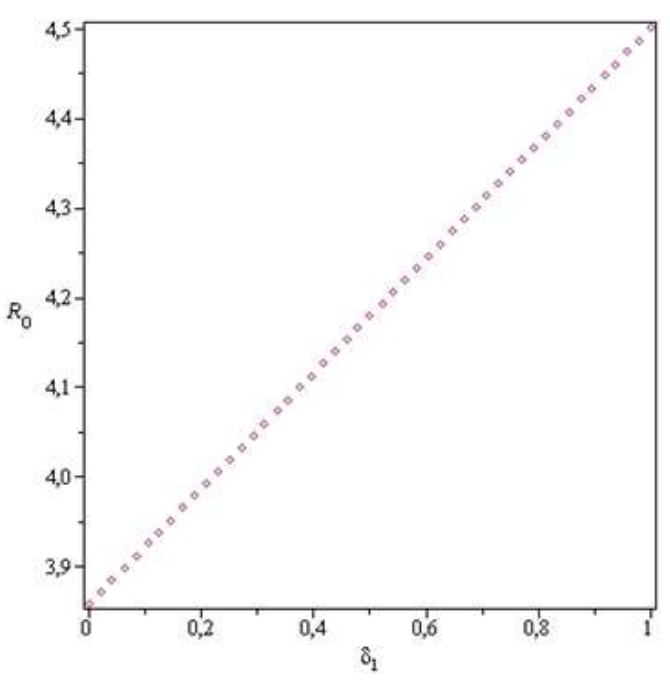

(a)

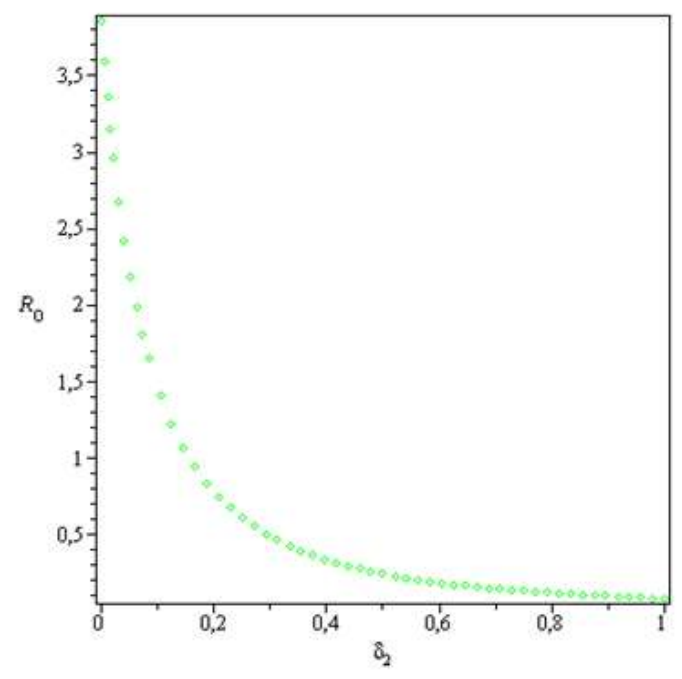

(b)

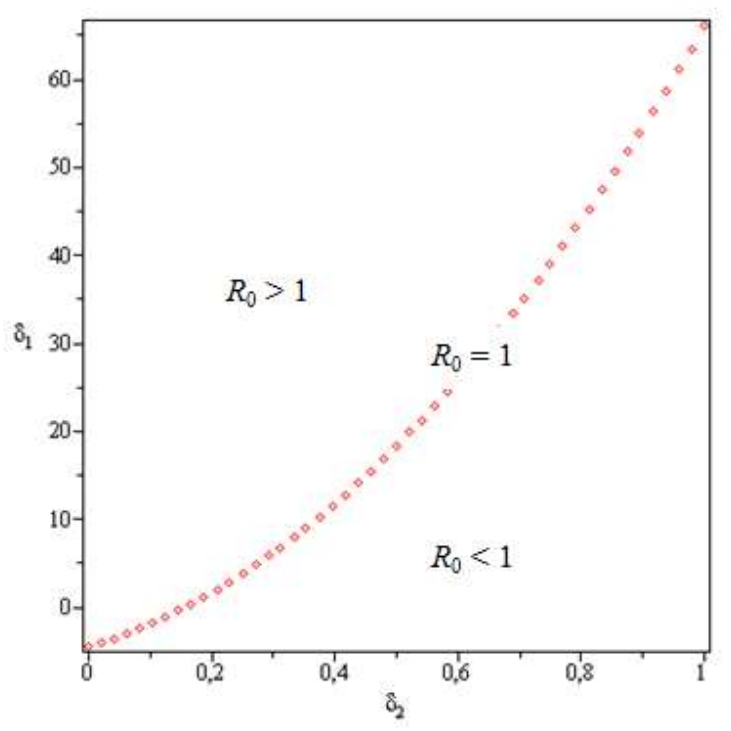

(c)

Gambar 5. Grafik dari $R_{0}$ ketika: (a) Perubahan nilai parameter $\delta_{1}$; (b) Perubahan nilai parameter $\delta_{2}$; (c) Perubahan nilai parameter $\delta_{1}$ dan $\delta_{2}$ ketika $R_{0}=1$.

\section{KESIMPULAN}

Pada penelitian ini ditunjukkan pengaruh migrasi manusia terhadap penyebaran campak. Berdasarkan hasil yang diperoleh, parameter migrasi memiliki pengaruh terhadap bilangan reproduksi dasar. Semakin besar nilai parameter imigrasi maka semakin besar peluang terjadi penyabaran penyakit pada suatu populasi. Selanjutnya, semakin besar nilai parameter emigrasi maka semakin kecil peluang terjadinya penyebaran penyakit di dalam populasi. Selanjutnya untuk menguragi penyebaran penyakit di dalam populasi maka dapat diupayakan vaksinasi dan pengobatan. 


\section{DAFTAR PUSTAKA}

Beay, L, K., Kasbawati., Toaha, S. 2017. Effects of human and mosquito migrations on the dynamical behavior of the spread of malaria. AIP Conference Proceedings $1825,020006$.

Fabricius, G., Bergero, P., Ormazabal, M., Maltz, A., Hozbor, D., 2013. Modelling pertussis transmission to evaluate the efectiveness of an adolescent booster in Argentina. Epidemiol. Infect. 141: 718-734.

Huang, S., Chen, F., Chen, L. 2017. Global dynamics of a network-based SIQRS epidemic model with demographics and vaccination. Commun Nonlinear Sci Numer Simulat $43: 296-310$.

Jody R., and Joyceen S, B. 2015. Forced migration: Health and human rights issues among refugee populations. NursOutlook 63: 68-76.

Pang, L., Ruan, S, Liu, S., Zhao, Z., Zhang, X. 2015. Transmission dynamics and optimal control of measles epidemics. Applied Mathematics and Computation 256: 131147.

Maltz, A., and Fabricius, G. 2016. SIR model with local and global infected contacts: A deterministic approach and applications. Theoretical Population Biology 112: 7079.

Sari, N., and Augeraud-Véron, E. 2015. Periodic orbits of a seasonal SIS epidemic model with migration. J. Math. Anal. Appl. 423: 1849-1866.

Soegijanto S, dan Salimo H. 2011. Campak. Pedoman imunisasi di Indonesia. 4th ed. Jakarta: Badan Penerbit IDAI; 2011. p. 341-5.

Tam, C.C. 2006. Analytic perspective. Migration and Health: Fact, Fiction, Art, Politics. Emerging Themes in Epidemiology : 1-5.

Wang, L and Wang, X. 2012. Influence of temporary migration on the transmission of infectious diseases in a migrants' home village. Journal of Theoretical Biology 300 : 100-109.

World Health Organization. 2015. Measles. http://www.who.int/ mediacentre/factsheets/fs286/en/. Diakses tanggal 11 Juni 2015. 